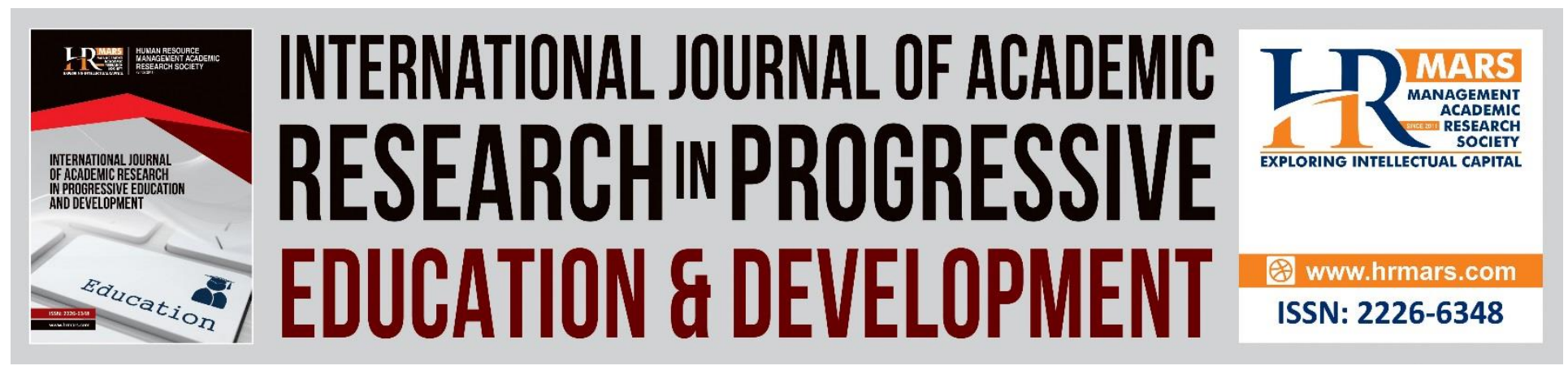

\title{
Pupils, Parents and Teachers Perceptions on Causes of Low Achievements in Kenya Certificate of Primary Education Examination: A Case Study in a Public School in Mandera County, Kenya
}

\author{
Mohamed Mahat Ali, Ahmed Osman Warfa
}

To Link this Article: http://dx.doi.org/10.6007/IJARPED/v7-i2/4167 DOI: 10.6007/IJARPED/v7-i2/4167

Received: 03 March 2018, Revised: 11 May 2018, Accepted: 25 May 2018

Published Online: 03 June 2018

In-Text Citation: (Ali \& Warfa, 2018)

To Cite this Article: Ali, M. M., \& Warfa, A. O. (2018). Pupils, Parents and Teachers Perceptions on Causes of Low Achievements in Kenya Certificate of Primary Education Examination: A Case Study in a Public School in Mandera County, Kenya. International Journal of Academic Research in Progressive Education and Development, $7(2)$.

\section{Copyright: (C) 2018 The Author(s)}

Published by Human Resource Management Academic Research Society (www.hrmars.com)

This article is published under the Creative Commons Attribution (CC BY 4.0) license. Anyone may reproduce, distribute, translate and create derivative works of this article (for both commercial and non-commercial purposes), subject to full attribution to the original publication and authors. The full terms of this license may be seen

at: http://creativecommons.org/licences/by/4.0/legalcode

\section{Vol. 7, No. 2, April 2018, Pg. 72 - 85}

Full Terms \& Conditions of access and use can be found at http://hrmars.com/index.php/pages/detail/publication-ethics 


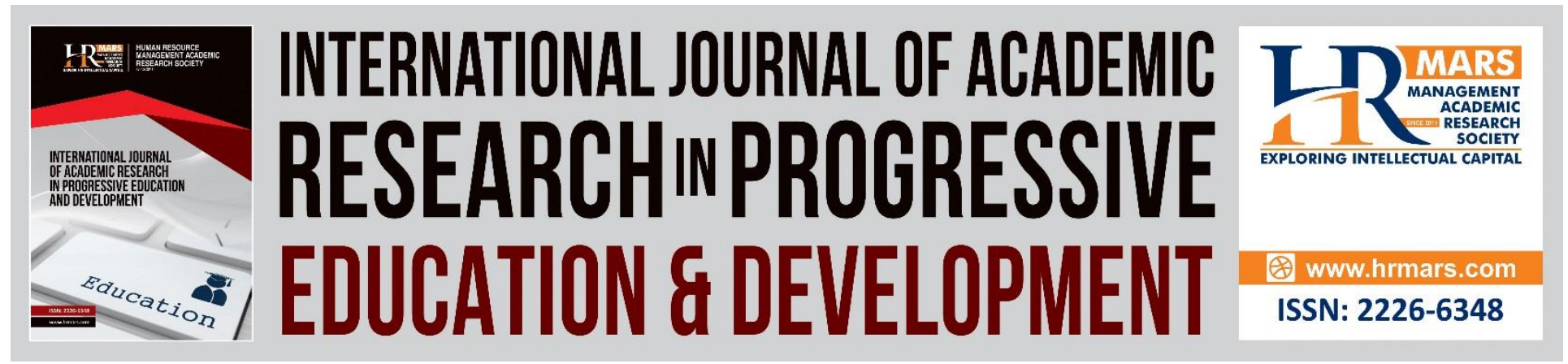

\title{
Pupils, Parents and Teachers Perceptions on Causes of Low Achievements in Kenya Certificate of Primary Education Examination: A Case Study in a Public School in Mandera County, Kenya
}

\author{
Mohamed Mahat Ali \\ Department of Curriculum, Instruction \& Media, School of Education, Arts and Social Sciences, \\ Garissa University, Kenya \\ Email: Mohamedmahat85@gmail.com
}

Ahmed Osman Warfa

Department of Curriculum, Instruction \& Media, School of Education, Arts and Social Sciences, Garissa University, Kenya

\begin{abstract}
The purpose of this study was to find out the pupils, parents and teachers' perceptions on causes of low achievement in Kenya Certificate of Primary Education (K.C.P.E) examination by public school pupils in Mandera County, Kenya. The study has employed qualitative research method. Semi-structured interview guides have been used to collect responses from the interviewees. Fifteen (15) participants who were grouped into three sets (six pupils, their six parents and three teachers) participated in the study. The interviewees gave a number of challenges they thought were the contributory factors and mitigation measures to the low pupils' achievement in the national examinations. A review of the school records has been used to collect data on the pupils' performance in the year 2015 K.C.P.E examinations as well the participants' demographic information.

Theoretically, this study has been guided by an integration of the conflict theory of education (Collins, 1971) and the education production function theory (Coleman S, 1966). The conflict theory of education helped in explaining the role of socioeconomic status of parents and pupils on the learners' academic achievement. Education production theory on the other hand was used to explain how the school system is seen as a 'market' where the society invests by use of 'input and output'. The study found that parents' low socioeconomic status, low parents' educational background, no learning follow up at home, insufficient teaching and learning resources, large class size \& shortage of teachers, pupils' low motivation to learn, poor learning
\end{abstract}


Vol. 7, No. 2, April 2018, E-ISSN: 2226-6348 @ 2018 HRMARS

strategies by pupils, low proficiency in languages of instruction, negative peer influence and truancy by the pupils were the causes of the low achievement in the national examinations.

The study's recommendations include: establishing adult literacy centers, promoting positive parents-teachers partnership on the pupils' academic activities, establishing sound economic uplifting programs that can improve the socioeconomic conditions of the society, providing enough \& relevant teaching/learning resources to schools and deployment of enough \& qualified teachers to schools.

Key words: Low achievement, Examinations, Primary education, Perceptions

\section{Introduction}

The Kenyan government has over the years placed a lot of importance to the education sector. The support for education by the government was and is as a result of the realization that an educated society can lead to an improvement in the national economy, development in other sectors as well as an individual's self-development and fulfillment. The need for quality and quantity education emanates from the public who demand the same and the respective governments have no option but to provide it (Ogola, 2010). In Kenya, children are usually taken to schools at the age of four-five years.

Economically, Kenya is classified in the developing countries' list by the World Bank. The East African nation is one of the sub-Saharan countries which are struggling to improve the economic conditions of their citizens (World Bank, 2015). Agriculture is the main economic activity supplemented by tourism and international grants. Education is one of the two sectors with the highest national total budgetary allocations.

\section{Education in Northeastern Kenya}

The North Eastern region is composed of three counties i.e. Mandera, Wajir and Garissa. According to the last population census that was conducted in Kenya in the year 2009, the region's population stood at 2,310, 757 out of the total national figure of 38,610, 097 according to the Kenya National Bureau of Statistics (2010). In most parts of North-eastern Kenya especially the rural areas, the main economic activities of the communities in the region are small scale businesses and nomadic lifestyle. Emphasis on these two economic activities coupled with low adult literacy has led the communities to disregard the significance of their children's schooling. Many children especially those in rural areas are accustomed to be livestock herders where they are made to look after domestic animals. Whereas those other children in towns are usually delegated many responsibilities like working in small scale businesses and as casual labourers. Culturally, the communities in this part of the country perceive schooling as an intrusion to their well-preserved traditions and norms. The people here believe that schooling would 'inculcate modern civilization' which they think can override their traditions like early marriage, division of labour, herding and other activities (Mauan, 2013). Although, some members of these communities have defied these prevailing circumstances and pursued education, still many members of these communities' have little or no formal education.

Parents have been blamed for their negative attitudes towards their children's schooling despite the government's effort to establish schools in almost all parts of the region both in towns and in rural areas. The introduction of Free Primary Education (FPE) in 2003 has led to some improvements in school enrolments in the region. Under the Free Primary Education program, 
Vol. 7, No. 2, April 2018, E-ISSN: 2226-6348 @ 2018 HRMARS

the government has waived the cost of some school facilities like building of classrooms and other facilities. The government also mobilised the people to take their children to schools. However, compared to the other counties in the country, there is still a glaring disparity in school attendance with North-eastern Kenya region still lagging behind, (Oketch and Mustisya, 2013).

\section{National Evaluation and Assessments in Kenyan Schools}

Upon completion of the primary school cycle, the pupils are required to sit for a national examination known as Kenya Certificate of Primary Education (K.C.P.E). In this exam the pupil is required to attain a maximum of 500 marks/points and a minimum of an average 250 marks in all the five subjects/courses taught in the primary schools i.e. English language, Swahili language, Mathematics, Science and Social Studies/Religious Education. If he or she passes this exam, the student will proceed to the secondary/high school where after 4 years he or she should again sit for another national exam known as Kenya Certificate of Secondary Education (K.C.S.E).

National examinations of schools in Kenya are usually administered by the national agency known as The Kenya National Examinations Council (KNEC). Due to the exam oriented nature of the education system, all stakeholders in the sector particularly parents and teachers expect the candidates to perform well in the national exams hence more pressure and drilling on the part of examination candidates.

Statement of the Problem of the Current Study

Since the year 2012, the education standard and the general pupils' academic achievement in Kenya Certificate of Primary Education (K.C.P.E) examination has been low in Mandera County than in any other County in the country (KNEC, 2013). Despite the use of the same curriculum and a uniform examination across the whole country, the examinees in Mandera County have continued to post low examinations results for long.

The government and the general public have raised concerns regarding the low achievement in national examinations. Some efforts were made to remedy the situation. For instance, the national government has introduced some incentives like School Feeding Program (SFP) where food rations or meals are given to the pupils by the school during the day in order to boost attendance of the learners. Mandera County government has also employed more untrained local teachers to supplement the schools' teaching staff. The School Management Committees (SMCs) of different public primary schools in Mandera County have also tasked the respective school administrations to organize for remedial lessons for examinees. Despite these efforts and other interventions by the education stakeholders, the students' achievements in Kenya Certificate Primary Education examinations have not seen any meaningful improvement.

The information in Figure1.1 has been sourced from the Kenya National Examinations Council's data base regarding the Kenya Certificate of Primary Education examinations results of the year 2013. 
INTERNATIONAL JOURNAL OF ACADEMIC RESEARCH IN PROGRESSIVE EDUCATION AND DEVELOPMENT

Vol. 7, No. 2, April 2018, E-ISSN: 2226-6348 @ 2018 HRMARS

Figure 1.1 Performance in K.C.P.E scores out of 500 points in some selected Counties in Kenya 2013

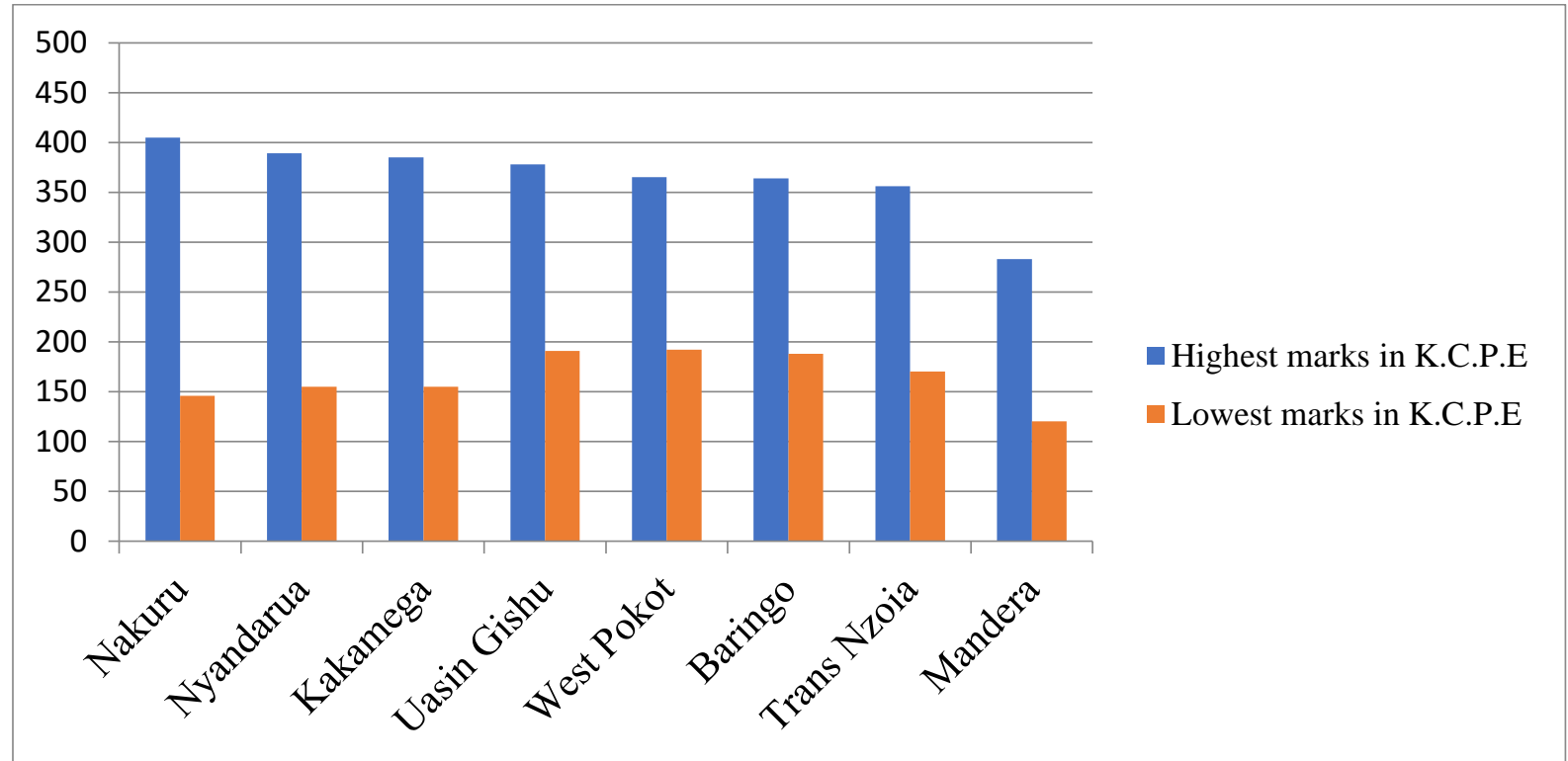

Source: KNEC \&Jagero (2013)

From Figure1.1 above, it is evident that Mandera county's candidates for K.C.P.E examinations in the year 2013 have performed dismally compared to their counterparts in the other seven counties represented in the figure. The student with the highest points in Mandera scored 283 out of maximum 500 points while the lowest candidate managed to score only 120 points out of 500. This means that with 120 points, this student could not get an admission to any high school in the country due to his or her poor examination results. The cut off points for admission in most high schools is 250 .

In the field of literature, there exist a number of studies that have attempted to find out factors affecting low or high achievement among students in learning institutions. For instance, Poole (1981) has observed that low economic status among households significantly contribute to low achievement in learning by students. Walberg (1984) also found out that pupils' aptitude, motivation/ intelligence, home environment, curriculum instructions/classroom environment, peer group/mass media affect the academic performance of the learners in schools.

In Kenyan perspective, some researchers have attempted to look into the factors influencing the students' performances in national examinations. One of these studies is Mulwa S. (2004) which highlighted the factors influencing the pupils' achievement in Kenya Certificate of Primary Education (K.C.P.E) examinations in Kitui County, Kenya. This study by Mulwa (2004) found that poverty, huge teachers' workload and absenteeism by students and teachers were the major contributors to the examinees' dismal performance.

A study by Muola (2010) found that there were significant relationships between parents' occupation, parents' level of education, learning facilities and academic achievement by the examinees. However, this study was conducted under controlled and predetermined variables quantitatively where the researcher manipulated the independent variables in line with his objectives. The available studies were also conducted in different contexts far from primary schools in Mandera County. This therefore prompted the need to carry out a qualitative case 
INTERNATIONAL JOURNAL OF ACADEMIC RESEARCH IN PROGRESSIVE EDUCATION AND DEVELOPMENT

Vol. 7, No. 2, April 2018, E-ISSN: 2226-6348 @ 2018 HRMARS

study on the contributory factors to low achievement in Kenya Certificate of Primary Education examinations: A case of public primary school pupils in Mandera County, Kenya.

Theoretically, this study has been guided by an integration of the conflict theory of education (Collins, 1971) and education production function theory (Coleman, S. 1966). The conflict theory of education states that schools vary to a greater extent in the availability of resources and funding which affect learning conditions and activities. This in turn leads to inequality and learning disparities which reinforces social inequality. The conflict theorists perceive schools as a powerful institution in maintaining social power stratification which perpetuates docile workers for the capitalist economic system (Collins, 1971).

Conflict theorists argue that schools with people who possess enough funds can continuously improve the quality of learning since they can attract and pay well the best teachers, buy the relevant and state of the art learning resources for their students. Students who enrol in those rich schools would be able to again an advantage in terms of getting admission to the best colleges and universities and would hence end up getting good jobs later. This will later raise their socio-economic status in society. On the other hand, learners from low economic status neighbourhoods who do not have enough funds will likely end up with low quality education hence they will exhibit low academic performance.

Education production function theory (Coleman, S. 1966) is actually understood to be the adaption of the economic concept of "production" to the field of education. It encompasses different aspects influencing learner's academic achievement. These include teachers, parents/guardians, schools, peer groups and the learners themselves. It posits that the inputs of these various stakeholders guided by policies will result in the pupils' academic performance measured in a standardised tests or scores.

\section{Research Questions}

1. What are the pupils, parents and teachers perceptions on causes of pupils' low achievement in Kenya Certificate of Primary Education examination?

2. What are the pupils, parents and teachers' suggestions on how to improve the achievement in Kenya Certificate of Primary Education examination?

\section{Methodology}

The study has employed qualitative research method. The target population of the study was all the 146 candidates who sat for those exams (K.C.P.E) in the year 2015 in one school in Mandera town. The sample of this study consisted of three class/grade eight teachers of the year 2015 cohorts, six pupils (one high achiever, one middle achiever and four low achievers in the K.C.P.E 2015 examinations) and their six parents. In total, the sample was 15 individuals selected from one public primary school in the Central Education Zone in Mandera East for the interviews. The four low achievers were selected because three quarters (3/4) of the 146 pupils who sat for that examination in that school in the year 2015 have performed below average (KNEC, 2015).

Semi-structured interview guides have been used to collect responses from the interviewees. The semi structured and the open ended questions were designed in a way that could capture the feelings and the perceptions of the teachers, pupils and their parents towards the contributory 


\section{INTERNATIONAL JOURNAL OF ACADEMIC RESEARCH IN PROGRESSIVE EDUCATION AND DEVELOPMENT}

Vol. 7, No. 2, April 2018, E-ISSN: 2226-6348 @ 2018 HRMARS

factors to low achievement in the national examinations and the possible recommendations for remedies.

Thematic approaches were used to analyse the data. The semi structured interview responses collected were categorised into three groups: The responses from the pupils, those from the parents and lastly the responses from the teachers. Each group of participants' responses were transcribed and analysed separately. The identified themes were regarded as the interviewees' perceptions towards the causes of the low achievements in the national examinations.

Table 3.1: Pupil participants' demographic information and achievement in K.C.P.E examinations in the year 2015

\begin{tabular}{|l|l|l|l|l|l|l|l|l|l|}
\hline Pupil & $\begin{array}{l}\text { Gende } \\
\mathbf{r}\end{array}$ & $\begin{array}{l}\text { Age } \\
\text { in } \\
\text { year } \\
\text { s }\end{array}$ & $\begin{array}{l}\text { No. of } \\
\text { days } \\
\text { absent } \\
\text { from } \\
\text { school } \\
\text { in 3 } \\
\text { month } \\
\text { s }\end{array}$ & $\begin{array}{l}\text { Englis } \\
\mathbf{h}\end{array}$ & $\begin{array}{l}\text { Kiswahil } \\
\mathbf{i}\end{array}$ & $\begin{array}{l}\text { Math } \\
\text { s }\end{array}$ & $\begin{array}{l}\text { Scienc } \\
\text { e }\end{array}$ & $\begin{array}{l}\text { Social } \\
\text { Studies \& } \\
\text { Religious } \\
\text { Educatio } \\
\mathbf{n}\end{array}$ & $\begin{array}{l}\text { Total } \\
\text { Scor } \\
\text { e }\end{array}$ \\
\hline Idle & Male & 17 & 19 & 59 & 56 & 51 & 58 & 71 & $\mathbf{2 9 5}$ \\
\hline Hamdi & Female & 15 & 18 & 50 & 47 & 42 & 62 & 50 & $\mathbf{2 5 1}$ \\
\hline Ahmed & Male & 14 & 16 & 22 & 31 & 20 & 26 & 37 & $\mathbf{1 3 6}$ \\
\hline Fartun & Female & 16 & 21 & 24 & 22 & 32 & 26 & 30 & $\mathbf{1 3 4}$ \\
\hline Siyad & Male & 15 & 24 & 20 & 25 & 28 & 26 & 29 & $\mathbf{1 2 8}$ \\
\hline $\begin{array}{l}\text { Marya } \\
\text { m }\end{array}$ & Female & 15 & 20 & 18 & 24 & 28 & 22 & 31 & $\mathbf{1 2 3}$ \\
\hline
\end{tabular}

Source: (Office of the head teacher of the case school)

Table 3.1 above shows the demographic information of the six pupils who participated in the study as interviewees. The pupils have all been given pseudonyms in order to conceal their identity. 
Vol. 7, No. 2, April 2018, E-ISSN: 2226-6348 ㄷ 2018 HRMARS

Table 3.2: Parents' Demographic Information

\begin{tabular}{|c|c|c|c|c|c|c|c|}
\hline Parent & Gender & $\begin{array}{l}\text { Occupati } \\
\text { on }\end{array}$ & $\begin{array}{l}\text { Parent } \\
\text { to pupil } \\
\text { participa } \\
\text { nt }\end{array}$ & $\begin{array}{l}\text { Average } \\
\text { monthly } \\
\text { income } \\
\text { in KES } \\
\text { \&USD }\end{array}$ & $\begin{array}{l}\text { No. of } \\
\text { family } \\
\text { members }\end{array}$ & Education & $\begin{array}{l}\text { No. of } \\
\text { visits to } \\
\text { the } \\
\text { school in } \\
3 \\
\text { months }\end{array}$ \\
\hline Roble & Male & Teacher & Idle & $\begin{array}{l}45,000 K \\
E S / 450 \$\end{array}$ & 8 & $\begin{array}{l}\text { With formal } \\
\text { education }\end{array}$ & 8 \\
\hline Khadija & Female & $\begin{array}{l}\text { Small } \\
\text { scale } \\
\text { business }\end{array}$ & Fartun & $\begin{array}{l}15,000 K \\
E S / 150 \$\end{array}$ & 4 & $\begin{array}{l}\text { without formal } \\
\text { education }\end{array}$ & 2 \\
\hline Jelle & Male & Farmer & Siyad & $\begin{array}{l}10,000 K \\
E S / 100 \$\end{array}$ & 6 & $\begin{array}{l}\text { without formal } \\
\text { education }\end{array}$ & 1 \\
\hline Hibo & Female & $\begin{array}{l}\text { Small } \\
\text { scale } \\
\text { business }\end{array}$ & Hamdi & $\begin{array}{l}20,000 K \\
E S / 200 \$\end{array}$ & 7 & $\begin{array}{l}\text { without formal } \\
\text { education }\end{array}$ & 3 \\
\hline Yusuf & Male & $\begin{array}{l}\text { Shopkee } \\
\text { per }\end{array}$ & Maryam & $\begin{array}{l}\text { 9000KES } \\
/ 90 \$\end{array}$ & 5 & $\begin{array}{l}\text { Primary school } \\
\text { leaver }\end{array}$ & 4 \\
\hline Halima & Female & $\begin{array}{l}\text { Vegetabl } \\
\text { e vender }\end{array}$ & Ahmed & $\begin{array}{l}\text { 8500KES } \\
/ 85 \$\end{array}$ & 4 & $\begin{array}{l}\text { without formal } \\
\text { education }\end{array}$ & 2 \\
\hline
\end{tabular}

Table 3.2 indicates the six parent participants' demographic information together with their respective sons and daughters who are also participants in this study. The parents have also been given pseudonyms for ethical consideration.

Table 3.3: Teachers' demographic information

\begin{tabular}{|l|l|l|l|l|l|}
\hline $\begin{array}{l}\text { Teacher } \\
\text { participant }\end{array}$ & Gender & Age & $\begin{array}{l}\text { Highest } \\
\text { qualification }\end{array}$ & $\begin{array}{l}\text { Teaching } \\
\text { experience } \\
\text { in years }\end{array}$ & $\begin{array}{l}\text { Number } \\
\text { of } \\
\text { lessons } \\
\text { per week }\end{array}$ \\
\hline Samow & Male & 34 & $\begin{array}{l}\text { Bachelor's } \\
\text { degree }\end{array}$ & 8 & 38 \\
\hline Felis & Female & 32 & $\begin{array}{l}\text { Primary } \\
\text { school } \\
\text { teacher } \\
\text { certificate }\end{array}$ & 15 & 36 \\
\hline Bishar & Male & 29 & $\begin{array}{l}\text { High school } \\
\text { certificate }\end{array}$ & 6 & 39 \\
\hline
\end{tabular}

Source: (Office of the head teacher of the case school) 
INTERNATIONAL JOURNAL OF ACADEMIC RESEARCH IN PROGRESSIVE EDUCATION AND DEVELOPMENT

Vol. 7, No. 2, April 2018, E-ISSN: 2226-6348 @ 2018 HRMARS

As indicated in table 3.3, three teachers teaching in the case school have participated in the study. All the three teachers have been involved in teaching and preparing the pupils in the final grade/class 8 for the K.C.P.E examinations. The teachers have also been given pseudonyms in order to safeguard their identity in this study.

Table 3.4: Components of the semi structured interview guides

\begin{tabular}{|c|c|c|}
\hline Interviewees & Themes & Items/questions asked concerning: \\
\hline \multirow[t]{3}{*}{$\begin{array}{l}\text { Pupils } \\
\text { Parents } \\
\text { Teachers }\end{array}$} & $\begin{array}{l}\text { Home Environment Factors affecting } \\
\text { Examination achievement }\end{array}$ & $\begin{array}{l}\text { - Parent/Guardian's income } \\
\text { - Parents/ Guardian's } \\
\text { educational background } \\
\text { - Parents-teachers partnership }\end{array}$ \\
\hline & $\begin{array}{l}\text { School Environment Factors affecting } \\
\text { Examination achievement }\end{array}$ & $\begin{array}{l}\text { - Teaching \& learning } \\
\text { resources } \\
\text { - Class size \&availability of } \\
\text { teachers } \\
\text { - Teaching strategies } \\
\text { - Teachers' qualifications \& } \\
\text { - Texperience } \\
\text { - Teachers' motivation }\end{array}$ \\
\hline & $\begin{array}{l}\text { Pupils' Aspects affecting Examination } \\
\text { achievement }\end{array}$ & $\begin{array}{l}\text { - Pupils' motivation to learn } \\
\text { - Attendance in school } \\
\text { - Learning strategies } \\
\text { - Proficiency in languages of } \\
\text { instruction } \\
\text { - Peer influence }\end{array}$ \\
\hline
\end{tabular}

\section{Findings}

Pupils, parents and teachers perceptions on causes of low achievement in Kenya Certificate of Primary Education examination

The pupils, parents and the teachers have shared a lot of similarities in perceptions and differed in a few instances as to the contributory factors to the low achievement in the Kenya Certificate of Primary Education (K.C.P.E) examinations. They have all perceived that (1) parents' low socioeconomic status, (2) low parents' educational background, (3) no learning follow up at home, (4) insufficient teaching \& learning resources, (5) large class size and shortage of teachers, (6) pupils' low motivation to learn, (7) poor learning strategies by pupils, (8) low proficiency in languages of instruction, (9) negative peer influence and (10) truancy by the pupils were the major causes of the low achievement in K.C.P.E.

The many similarities in perceptions by the three groups of interviewees can be construed as a way of validating the data collection methods (Wiersma \& G. Jurs, 2009). The similarities in perceptions can also be attributed to the fact that the study investigated one particular 
Vol. 7, No. 2, April 2018, E-ISSN: 2226-6348 @ 2018 HRMARS

phenomenon i.e. the teachers', pupils' and parents' perceptions on causes of low achievement by pupils in the K.C.P.E examinations in a pubic primary school in Mandera County, Kenya. The semi structured interview questions for the pupils, parents and the teachers were also somehow similar in structure though the wordings might have been different for the purpose of clarity.

The following are some excerpts of the interviewees' responses to some of the questions posed to them during the data collection stage.

The pupils felt the effects of low or lack of formal education literacy by their parents on their academic achievement. Hamdi, a pupil said, "My parents could not help me to do my homework simply because they have not gone to school themselves. That means they could not understand what my home work was about, however they have been encouraging me to finish my homework".

The pupils raised some concerns about the insufficient teaching and learning resources in the school. They have admitted that the relevant teaching and learning resources were inadequate. Fartun a pupil said, "As far as teaching and learning resources were concerned, there were insufficient to all the pupils in our school. If the pupils do not have enough learning materials like books, pens and other facilities like classrooms, desks and libraries, we do not expect them to do well in the national examinations like K.C.P.E".

The parents have stated that low economic condition affected the schooling and the general welfare of their children. Khadija, a mother said, "I have been a single parent since the father of my three children passed on many years ago. I have been grappling with harsh economic conditions for long. Sometimes, I run out of cash, making me unable to buy the necessary learning materials for my children".

Just as the pupils have mentioned earlier, their parents also believe that their lack of or low level of educational background has been a contributory factor to their children's low achievement in the examinations.

Hibo (a mother) said, "As uneducated mother, I could not help my daughter with her assignments and revisions as a parent. If I had the ability, I would have sometimes guided and corrected her". The parents were also asked whether the school had enough teachers to teach the pupils. On this, the parents mentioned that the school was understaffed, despite being the most populous public primary school in Mandera town. Halima, a mother said, "If you look at the high enrolment of pupils in the school and the number of teachers teaching here, you can easily understand that there is a high shortage of teachers. One of the teachers in the school once told me that there were around 120 pupils in one class".

According to the teachers, the other contributing factor to low achievement in the national examinations was irregular or no parents-teachers partnership. The teachers said that the parents did little to interact with the school authorities and the teachers to monitor their children's performance. Samow. a teacher said, "There is no clear partnership between teachers and parents on matters regarding the pupils' academic achievement. This is according to my experience for the last 7 years I have been teaching in this school....."

The teachers who participated in this study have admitted that their pupils did adopt good learning strategies. Bishar, a teacher said, "...... unfortunately, here in our school, pupils have not 
INTERNATIONAL JOURNAL OF ACADEMIC RESEARCH IN PROGRESSIVE EDUCATION AND DEVELOPMENT

Vol. 7, No. 2, April 2018, E-ISSN: 2226-6348 @ 2018 HRMARS

been organizing their learning strategies effectively. Maybe this is due to lack of guidance by the teachers and parents or due to the pupils' low motivation towards learning".

However, some differences in perceptions among the pupils, parents and the teachers were noted. Whereas the pupils perceived that harsh conditions in the area was also responsible for the low achievement, the parents on the other hand perceived that low teachers' motivation to teach was also another factor. Yet the teachers had also shared that child labour, low teacher qualifications \& experience and irregular or no parents-teachers partnership were additional contributory factors.

\section{Suggestions on how to improve the achievement in Kenya Certificate of Primary Education examination}

Based on their experiences and knowledge of the study objectives, the interviewees have shared and proposed some crucial measures in which they thought could address the problem of low achievement in the K.C.P.E examinations. The three groups of participants have also shared some of their recommendations and at the same time differed on others. The pupils, parents and the teachers have collectively suggested that there should be an enhanced parents-teachers' partnership, motivation of the teachers and the pupils, provision of enough learning resources and the deployment of more teachers to curb teachers' shortage.

Differences in recommendations by the three groups of interviewees were however noted. The pupils who were the owners of the said low achievement have recommended that there should be an improvement in the teaching methods and the provision of guidance $\&$ counselling against pupils' truancy from the school. The pupils have argued that many of their teachers did not make them comprehend the concept being taught in the classroom probably due to the teacher's ineffective teaching strategies.

The parents have also recommended that an effort should be made to improve the English and Kiswahili languages proficiencies among the pupils and the teachers should be motivated by the government. Teachers too had their unique recommendations which included the provision of adult literacy programs for the parents and prompt syllabus coverage. The teachers believed that due to the high number of parents with no formal education in the society, many parents could not recognise and appreciate the value of their children's schooling.

Table 5.1 below summarizes the contributory factors to the low achievement in the K.C.P.E examinations and the recommendations on how to curb these challenges as perceived by the interviewees. 
Vol. 7, No. 2, April 2018, E-ISSN: 2226-6348 @ 2018 HRMARS

Table 5.1: Summary of the Findings

\begin{tabular}{|c|c|c|c|c|}
\hline \multirow[b]{3}{*}{$\begin{array}{l}\text { Pupils, Parents } \\
\text { and Teachers' } \\
\text { Perceptions on } \\
\text { the contributory } \\
\text { factors to low } \\
\text { achievement in } \\
\text { national } \\
\text { examinations }\end{array}$} & \multirow[b]{3}{*}{$\begin{array}{l}\text { Similarities in perceptions } \\
\text { Parents' low socioeconomic } \\
\text { status, Low parents' } \\
\text { educational background, No } \\
\text { learning follow up at home, } \\
\text { Insufficient Teaching and } \\
\text { Learning Resources, Large class } \\
\text { size and shortage of teachers, } \\
\text { Pupils' low motivation to learn, } \\
\text { Poor learning strategies by } \\
\text { pupils, Low proficiency in } \\
\text { languages of instruction, } \\
\text { Negative peer influence and } \\
\text { Truancy by the pupils }\end{array}$} & \multicolumn{3}{|c|}{ Differences in perceptions } \\
\hline & & Pupils & Parents & Teachers \\
\hline & & $\begin{array}{l}\text { Poor teaching } \\
\text { strategies and } \\
\text { Harsh Climatic } \\
\text { condition }\end{array}$ & $\begin{array}{l}\text { Low teachers' } \\
\text { motivation to } \\
\text { teach }\end{array}$ & $\begin{array}{l}\text { Child labour, } \\
\text { Low teachers' } \\
\text { qualifications } \\
\& \text { experience } \\
\text { and Irregular } \\
\text { or no parents- } \\
\text { teachers } \\
\text { partnership }\end{array}$ \\
\hline $\begin{array}{l}\text { Strategies on } \\
\text { how to mitigate } \\
\text { the low } \\
\text { achievement in } \\
\text { K.C.P.E } \\
\text { examinations }\end{array}$ & $\begin{array}{l}\text { Promote parents-teachers' } \\
\text { partnership, Motivate the } \\
\text { teachers and the pupils, Provide } \\
\text { enough learning resources, } \\
\text { deployment of more teachers to } \\
\text { curb teachers' shortage. }\end{array}$ & $\begin{array}{l}\text { Improve the } \\
\text { teaching } \\
\text { methods, } \\
\text { guidance \& } \\
\text { counselling } \\
\text { against pupils' } \\
\text { truancy }\end{array}$ & $\begin{array}{l}\text { Improve English } \\
\text { and Kiswahili } \\
\text { languages } \\
\text { proficiencies, } \\
\text { motivate the } \\
\text { teachers by } \\
\text { improving their } \\
\text { working } \\
\text { conditions, }\end{array}$ & $\begin{array}{l}\text { Provide adult } \\
\text { literacy } \\
\text { programs for } \\
\text { the parents, } \\
\text { prompt } \\
\text { syllabus } \\
\text { coverage }\end{array}$ \\
\hline
\end{tabular}

\section{Discussion}

The pupils, parents and the teachers have shared a lot of similarities in perceptions and differed in a few instances as to the contributory factors to the low achievement in the Kenya Certificate of Primary Education (K.C.P.E) examinations. They have all perceived that (1) parents' low socioeconomic status, (2) low parents' educational background, (3) no learning follow up at home, (4) insufficient teaching \& learning resources, (5) large class size and shortage of teachers, (6) pupils' low motivation to learn, (7) poor learning strategies by pupils, (8) low proficiency in languages of instruction, (9) negative peer influence and (10) truancy by the pupils were the major causes of the low achievement in K.C.P.E. However, instances of some differences in perceptions among the pupils, parents and the teachers were noted.

It is worthwhile to note that the findings of this qualitative study are in agreement with findings of many other studies mentioned in the literature review of this study. A case in point of such a study is the one conducted by Walberg (1984) which found out that pupils' aptitude, motivation, home environment, curriculum instructions, classroom environment and peer groups affect the academic performance of the learners in schools. Furthermore, the findings of this study are in conformity with the conflict theory of education (Collins, 1971) and education production function theory (Coleman S, 1966). The low socioeconomic status of the parents as a major cause 
INTERNATIONAL JOURNAL OF ACADEMIC RESEARCH IN PROGRESSIVE EDUCATION AND DEVELOPMENT

Vol. 7, No. 2, April 2018, E-ISSN: 2226-6348 @ 2018 HRMARS

of low academic achievement as postulated by the conflict theory of education is in line with the findings of this study.

Conclusions and Recommendations

The study found that parents' low socioeconomic status, low parents' educational background, no learning follow up at home, insufficient teaching and learning resources, large class size \& shortage of teachers, pupils' low motivation to learn, poor learning strategies by pupils, low proficiency in languages of instruction, negative peer influence and truancy by the pupils were the causes of the low achievement in the national examinations.

\section{Suggestions for Policy Makers}

The study unearthed numerous challenges contributing to the pupils' low achievement in K.C.P.E examinations. The participants (pupils, parents and the teachers) have perceived that if these challenges are tackled, then the examinations results will improve. The national and the county governments are therefore urged to:

i. Establish adult literacy centers where the parents and other senior members of the society can be taught the basic literacy and numeracy skills. This will go a long way in sensitizing the parents to appreciate the value of education hence would help encourage their children to perform in the national examinations. This recommendation is informed by the teachers' perceptions that low literacy among the parents is a contributory factor to the examinees' dismal examinations achievement.

ii. Promote positive parents-teachers partnership on the pupils' academic activities. This may help in uplifting the achievement in the national examinations. It is worth noting that the parents and teachers interviewed in this study have actually admitted that the parentsteachers' partnership in the school understudy was wanting or irregular.

iii. Propose and establish sound economic uplifting programs that can improve the socioeconomic conditions of the society. This will be done on the pretext that low socioeconomic conditions of the parents is a major contributory factor to the low achievement in the national examinations as perceived by all the interviewees in this study.

iv. Provide enough and relevant teaching and learning resources to the school for smooth learning activities. As shown in the findings chapter, almost all the participants in this study have attributed the low achievement in the national examinations to the insufficient teaching and resources in the school.

v. Deploy enough and qualified teachers to schools. Shortages of teachers and large class size have been cited as some of the major contributory factors to the low examination achievement by the participants in this study.

vi. Establish counseling and psychological support centers in schools in order to mitigate truancy, indiscipline and drug abuse. This is because truancy and negative peer influence have contributed to the low exam achievement according to the pupils, parents and teachers in this study. 


\section{Recommendations for Further Research}

This study investigated the pupils', parents and teachers' perceptions on causes of low achievement by pupils in the K.C.P.E examinations in a pubic primary school in Mandera County, Kenya. The study recommends that future researches should focus on:

i. A similar study in secondary schools in Mandera with special focus on the national examinations of Kenya Certificate of Secondary Education (K.C.S.E) achievement.

ii. A similar study with increased sample size in the entire Northeastern Kenya in order to assess if these challenges are common in the whole region.

iii. Assessment of dropout rates and patterns in both primary and secondary schools occasioned by low national examination achievement.

\section{References}

Collins, R. (1971). Functional and conflict theories of educational stratification. American sociological review, 1002-1019

Jagero, N. (2013). Poverty Level and Kenya certificate of primary education performance in Kenya. British Journal of Humanities and Social Sciences, Vol 9:1, 18-26.

Maiyo, L., Sanghi, A. \& Bundervoet, T., (2015). Bright lights, big cities: measuring national and subnational economic growth in Africa from outer space, with an application to Kenya

and Rwanda. Conference Paper, Kigali. Presented by: Kenya and Rwanda Country Management Unit Macroeconomics and Fiscal Management \& Poverty Global Practice Groups.

Mauan, L. B. (2013). Factors influencing academic performance of girls in public primary schools in Sereolipi Education Zone in Samburu County, Kenya. (Unpublished Master of Arts Thesis). The University of Nairobi. Nairobi, Kenya.

Mulwa S. (2004). Factors influencing pupils' academic performance in K.C.P.E examination in Mutonguni division in Kitui district. (Unpublished Master Thesis). The University of Nairobi. Nairobi, Nairobi, Kenya.

Muola, J. M. (2010). A study of the relationship between academic achievement motivation and home environment among standard eight pupils. Educational Research and Reviews, 5(5), 213.

Ogola, F. O. (2010). Free education in Kenya's public primary schools. Addressing the challenges. Organization for Social Science Research in Eastern and Southern Africa (OSSREA). Addis Ababa, Ethiopia, Vol 7:3, 10-19.

Oketch, M., Mutisya, M. (2013). Evolutional of Educational Outcomes in Kenya. Nairobi: Background paper prepared for the Education for All Global Monitoring Report, Teaching and learning: Achieving quality for all.

Poole, A. (1981).Educational Opportunities for Minority Groups. In world yearbook of Education: Education of Minorities. New York: London/Nichols Publishing Company.

Walberg, H. J. (1984). Improving the Productivity of American Schools. Illinois: Publication of College of Education, university of Illinois in Chicago.

Wiersma, W., \& Jurs, S. G. (2009). Research methods in education 9th edition. Allyn-Bacon: Boston, MA. 